\title{
Effect of different salinity levels on plant growth parameters of tomato
}

G. Sridevi

MEMBERS OF RESEARCH FORUM:

Corresponding author :

G. Sridevi, Department of Soil Science and Agricultural Chemsitry, Tamil Nadu Agricultural University, Coimbatore (T.N.) India

Email: smathareddy@gmail.com
Received : 21.08.2020; Revised : 07.11.2020; Accepted : 20.11.2020

\section{Summary}

Soil and water salinity is one of the major problems in the world for agricultural production. Tomato is one of the ten most important fruit and vegetables consumed in the world, with approximately one hundred million tonnes of fresh tomato fruit being produced worldwide every year. This research was conducted to determine the different evels of EC d S m${ }^{-1}$ in irrigation water collected from Central Farm well water and Bore well water of Agricultural College and Research Institute, Madurai and Periyar Vaigai Command water in the year 2018 were evaluated Based on their growth and yield of tomato (PKM 1). The results indicated that there was consistent decrease in yield with increase in salt concentration in saline irrigation water and yield and it was found that the maximum salinity tolerance is $2 \mathrm{~d} \mathrm{~S} \mathrm{~m}^{-1}$.

Key words : Tomato, Salinity, Yield

How to cite this article: Sridevi, G. (2020). Effect of different salinity levels on plant growth parameters of tomato. Asian J. Soil Sci., 15(2): 97-100 : DOI : 10.15740/HAS/AJSS/15.2/97-100. Copyright@2020: Hind Agri-Horticultural Society.

\section{Introduction}

Seventy per cent $(70 \%)$ of the earth surface is covered with water, which amounts to 1400 million cubic kilometres $(\mathrm{m} \mathrm{km} 3)$. However, 97.5 per cent of this water being sea water, it is salty. Fresh water availability is only $35 \mathrm{~m} \mathrm{~km} 3$. Out of the total fresh water, 68.7 per cent is frozen in ice caps, 30 per cent is stored underground and only 0.3 per cent water is available on the surface of the earth. Out of the surface water, 87 per cent is stored in lakes, 11 per cent in swamp and 2 per cent in rivers. As all the sweet water is not extractable, only 1 per cent of the total water can be used by human beings (Anonymous, 2006).

As water was available in plenty, it was considered as a free resource since generations. However, with growing demand for water and depletion of the available water, assured supply of good quality water is becoming a growing concern. As the water resources are not evenly distributed, across different continents, some countries have surplus water while many other countries are facing scarcity of water. Likewise, there is skewed growth of population in different continents, resulting in a wide mismatch between the existing population and water availability. Among various continents, Asia has 36 per cent of the available fresh water reserves, with over 60 per cent of the world population where water is a scarce commodity.

Salt stress affects some major processes such as germination, speed of germination, root/shoot dry weightand $\mathrm{Na}^{+} / \mathrm{K}^{+}$ratio in root and shoot (Parida and Das, 2005). Salinity tolerance is critical during the life cycle of anyspecies. The maximum soil salinity tolerated 